\title{
Radical Mechanism in the Elimination of 2-Arylsulfinyl Esters
}

Antonio Latorre, Irakusne López, Victoria Ramírez, Santiago Rodríguez, Javier Izquierdo, Florenci V. González* and Cristian Vicent*

Departament de Química Inorgànica i Orgànica, Universitat Jaume I, 12080 Castelló, Spain

Serveis Centrals d'Instrumentació Científica, Universitat Jaume I, 12080, Castelló, Spain

fgonzale@qio.uji.es,barrera@sg.uji.es

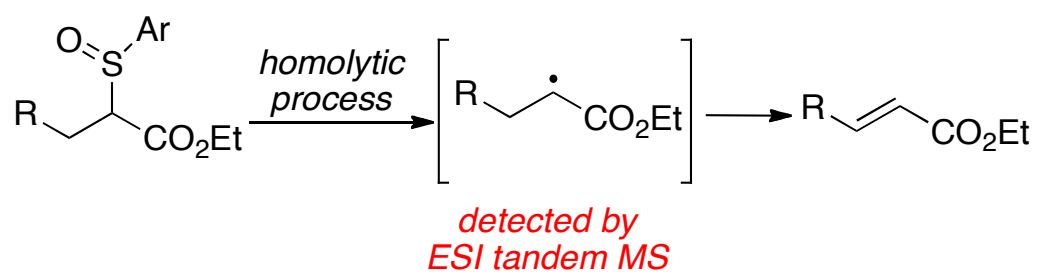

\begin{abstract}
The mechanism of the dehydrosulfenylation of 2-arylsulfinyl esters was investigated. The reaction was found to follow a homolytic cleavage mechanism as verified by electrospray ionization tandem mass spectrometry and experimental work. Rearranged sulfoxides are obtained as by-products during the elimination reaction.
\end{abstract}

Elimination reactions of sulfoxides and sulfones are well known reactions in synthetic organic chemistry. ${ }^{1}$ Particularly, the transformation of 2-arylsulfinyl esters to afford unsaturated carbonyl compounds by elimination is a common synthetic transformation. ${ }^{2-5}$ The elimination reaction of sulfoxides follows an Ei (elimination internal) mechanism, as demonstrated by the seminal work by Cram and Kingsbury, ${ }^{6}$ who also suggested the existence of a competing homolytic mechanism for some sulfoxides having a group to stabilize a radical intermediate. Although extensive work has been reported for the elimination of sulfoxides through an Ei mechanism, ${ }^{7-8}$ no convincing evidence has appeared for a radical mechanism involving any sulfinyl substrate. 
In the context of our investigations with sulfoxides, ${ }^{9-10}$ we became interested in determining the nature of the mechanism during the elimination reaction of 2-arylsulfinyl esters. We considered two plausible mechanistic routes for the elimination of a 2-arylsulfinyl ester to afford the corresponding enoate (Scheme 1): a) the concerted elimination reaction (Ei), or b) a radical process involving the homolytic scission of the C-S bond to furnish free radical 4 and aryl sulfinyl radical 3.

(a)

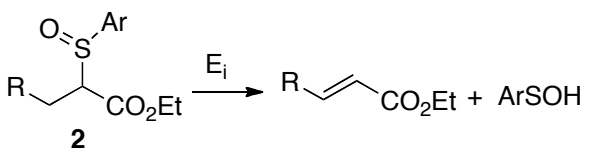

(b)

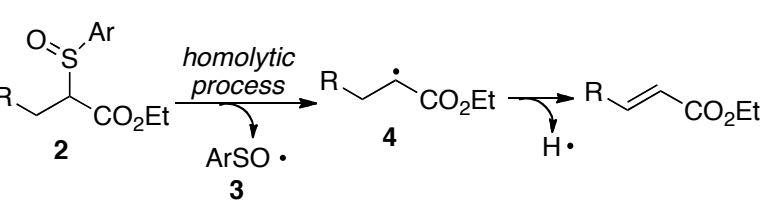

Scheme 1. Possible mechanistic routes.

We undertook the study of the elimination reaction of 2-arylsulfinyl esters with a range of $\mathrm{R}$ alkyl groups and Ar aryl groups attached to the sulfur atom. 2-Arylsulfinyl esters 2a-f were prepared from the corresponding 2-bromo esters by treatment with the corresponding sodium thiophenolates, which furnished the expected thioethers 1a-f. Upon oxidation of the thioethers, sulfoxides $\mathbf{2 a - f}$ were obtained as a mixture of stereoisomers (Scheme 2$).{ }^{11}$ Then compounds 2 a-f were submitted to elimination by heating to reflux in toluene for $5 \mathrm{~h}$, affording the corresponding $E$ enoates. $^{12}$ 2-Arylsulfinyl esters $\mathbf{2 a - c}$ gave rise to ethyl acrylate $\mathbf{5}$ and compounds $\mathbf{2 d}, \mathbf{2 e}$ and $\mathbf{2 f}$ afforded enoates $\mathbf{6}, \mathbf{7}$ and $\mathbf{8}$ respectively as dominant products. ${ }^{13}$

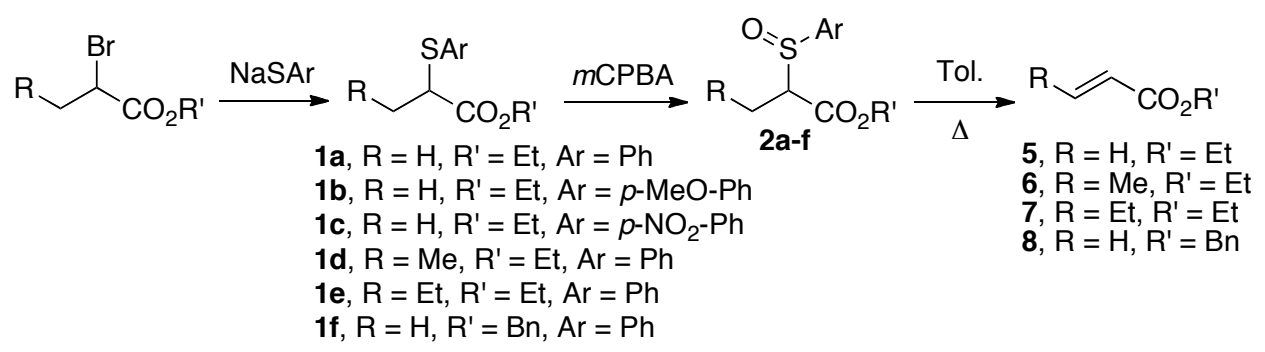

Scheme 2. Preparation and elimination of 2-arylsulfinyl esters 2a-f. 
Careful isolation of all the products obtained during the elimination reaction of compound 2a gave the phenylthiosulfonate 9 (that partly converts to diphenyldisulfide and sulfonic acid, see below) and rearranged sulfoxide 10 as a minor product (15\%) (Scheme 3$).{ }^{14}$

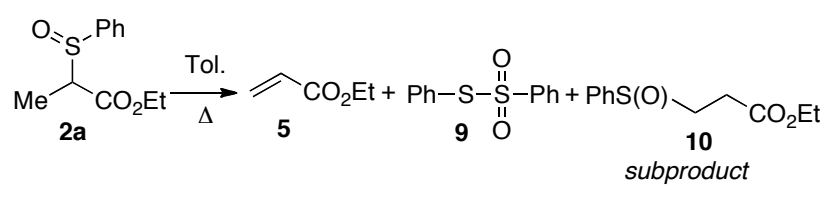

Scheme 3. Elimination reaction of compound $\mathbf{2 a}$.

It is also noteworthy that the unprecedented rearrangement of 2-arylsulfinyl ester $\mathbf{2 a}$ to yield $\mathbf{1 0}$ provided an alternative synthetic entry to 3-arylsulfinyl ester. To determine whether the formation of minor compound $\mathbf{1 0}$ was an inter- or an intramolecular process, we conducted a crossover experiment between $\mathbf{2 b}$ and compound $\mathbf{2 f}$ (see Scheme 4).

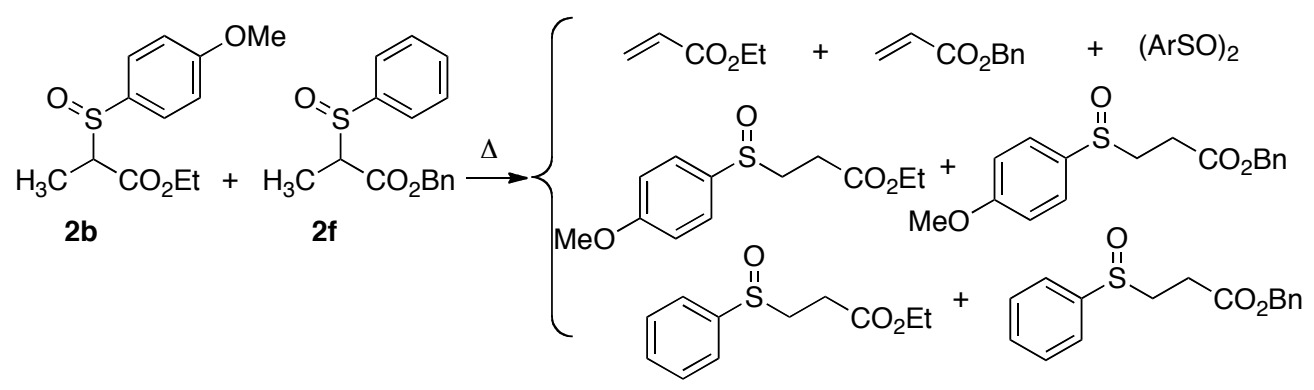

Scheme 4. Crossover experiment between $\mathbf{2 b}$ and $\mathbf{2 f}$.

After heating of both sulfoxides $\mathbf{2 b}$ and $\mathbf{2 f}$, the ${ }^{1} \mathrm{H}$ NMR or ${ }^{13} \mathrm{C}$ NMR spectra were highly crowded due to the presence of numerous species, making it difficult to identify the newly formed species. However, after removal of volatile acrylates and chromatographic separation of the fraction containing the 3-arylsulfinyl esters and the thiolsulfonate esters, electrospray ionization mass spectrometry (ESI-MS) analysis, operated in positive ion mode $(\mathrm{ESI}(+))$, unravelled a rapid and direct snapshot of the formed species in the reaction mixture (see Figures S1 and 
S2), and demonstrated that the rearrangement was an intermolecular rather than an intramolecular process. ${ }^{15} \mathrm{~A}$ similar result was observed when sulfoxides $\mathbf{2 b}$ and $\mathbf{2 e}$ were heated at $80^{\circ} \mathrm{C}$ for $2 \mathrm{~h}$ as judged by ESI-MS analysis.

The corresponding 2-arylsulfonyl esters were also prepared. When 2-arylsulfonyl esters or 2-arylthioethers (1a-f) underwent the same experimental conditions for elimination as the sulfoxides, only starting material was recovered, thus illustrating that eliminations are a characteristic feature of only the sulfoxides.

Since the photolytic homolysis of C-S bonds have been described, ${ }^{16}$ the elimination reactions were also performed in the absence of light. When 2-arylsulfinyl esters 2a-f were submitted to elimination by heating in the absence of light the products were the same as in the presence of light thus ruling out a photolytic homolysis.

The interception of the radical intermediates would provide evidence for presence of a single-electron transfer mechanism in the elimination reaction. A nitroxyl radical (2,2,6,6-Tetramethyl-1-piperidinyloxy) (Tempo) succeeded in intercepting the radical intermediates derived from 2-arylsulfinyl esters $\mathbf{2 b}, \mathbf{2 d}$ and $\mathbf{2 e}$. The reactions were investigated by electrospray ionization mass spectrometry (ESI-MS). ${ }^{17}$ Compounds $\mathbf{2 b}, \mathbf{2 d}$ and $\mathbf{2 e}$ afforded adducts 11 and 15,12 and 14 , and 13 and 14 respectively. In case of the reaction using $2 \mathrm{e}$ as starting material, both resulting reaction compounds 13 and $\mathbf{1 4}$ were isolated and fully characterized (see Supporting Information) (Scheme 5). ${ }^{18}$

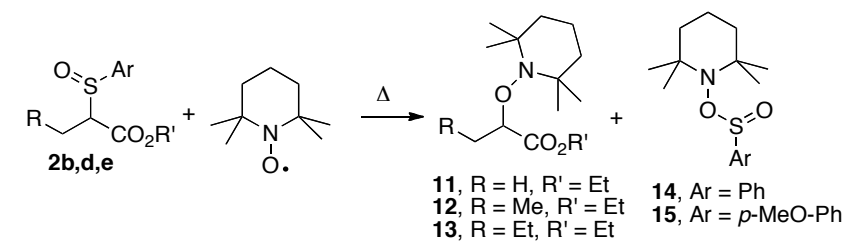

Scheme 5. Trapping of the radical intermediates using Tempo.

These results denote the occurrence of a radical process during the elimination of 2-arylsulfinyl esters into enoates. A possible mechanism is proposed in Scheme 6. Sulfoxide 2 would give rise to radical 4 and aryl sulfinyl radical 3. Sulfinyl radicals combine to give vicinal disulfoxides (vic-disulfoxides) which isomerize to give phenyl thiosulfonate 9. Thiosulfonate $\mathbf{9}$ partly converts into the corresponding diaryl sulfide $\mathbf{1 6}$ and sulfonic acid as it is known. ${ }^{19}$ Radical $\mathbf{4}$ would furnish the enoate. The formation of the subproduct $\mathbf{1 0}$ can be explained by addition of in situ-formed phenyl sulfenic acid to the enoate. The addition of sulfenic acids to unsaturated esters have been 
demonstrated previously. ${ }^{20-22}$ Compound $\mathbf{1 0}$ would be formed in a low yield due to the high tendency of sulfinyl radicals (or sulfenic acids) to afford thiosulphonates, although final reaction yields would depend on the subtle interplay between kinetics and thermodynamics of each elementary step depicted in Scheme 6 .

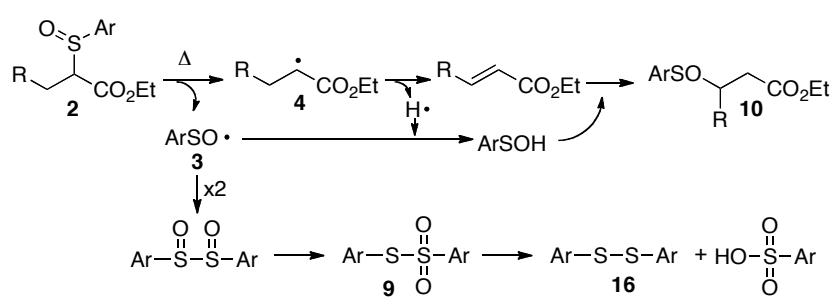

Scheme 6. Radical Mechanism in the Elimination of 2-Arylsulfinyl Esters

In studies to determine the reaction mechanism of a multistep reaction, the identification of the intermediates is an essential process. ${ }^{23}$ In this context, ESI-MS is a useful technique for analyzing chemical intermediates or products in diverse chemical and biochemical processes, ${ }^{24-26}$ as illustrated above for the identification of the products formed in the crossover experiment. Although the detection of free radicals is sometimes difficult, ESI-MS has been recently employed for observing radical intermediates in some processes. ${ }^{27-32}$ For a better understanding of the mechanism of the arylsulfinyl esters elimination depicted in Scheme 6, attempts to intercept and characterize the formed species were carried out on the basis of on-line ESI mass spectrometry and ESI tandem mass spectrometry. Closely related thermally-driven homolytic reactions have been successfully investigated by Metzger's group by means of ESI mass spectrometry using modified ESI sources. ${ }^{28}$ To investigate the elimination reaction, toluene solutions of $2 \mathbf{a}$ were heated to $100{ }^{\circ} \mathrm{C}$ and at different time intervals, aliquots were extracted, immediately diluted with hot acetonitrile, and analyzed by $\operatorname{ESI}(+)$ mass spectrometry. The obtained ESI mass spectra recorded at different intervals were nearly identical (Figure 1), with the most significant difference being the appearance of new signals corresponding to the $\mathrm{PhSSO}_{2} \mathrm{Ph}$ product as evidenced for the peaks assigned to $\left[\mathrm{PhSSO}_{2} \mathrm{Ph}+\mathrm{Na}\right]^{+}(\mathrm{m} / \mathrm{z}=273)$ and $\left[\mathrm{PhSSO}_{2} \mathrm{Ph}+\mathrm{K}\right]+(\mathrm{m} / \mathrm{z}=289)$. Negative ESI mass spectrum revealed the presence of sulfonic acid as $[\mathrm{M}-\mathrm{H}]^{-}$ adduct. Diphenyldisulfide was not observed in the ESI mass spectrum because it is not readily ionized upon ESI conditions. 


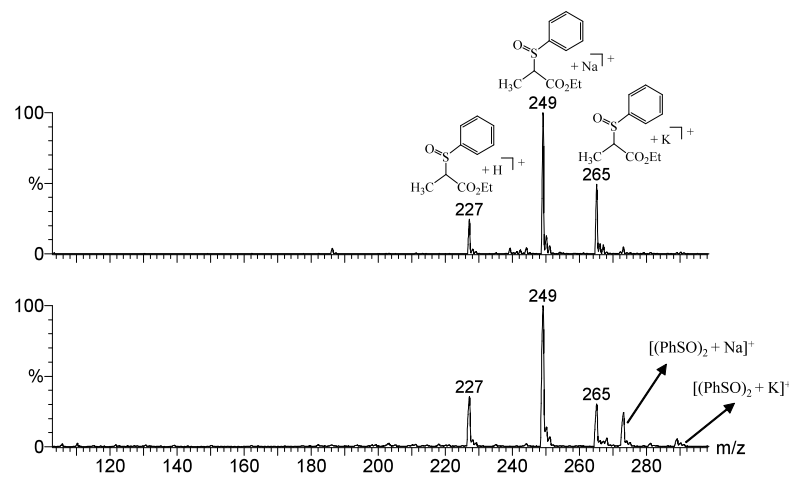

Figure 1. ESI $(+)$ mass spectra of toluene/acetonitrile solutions of compound 2a. Samples of the initial solution of 2a (upper panel) and of compound 2a after heating for $60 \mathrm{~min}$ (lower panel). Note that species at $\mathrm{m} / \mathrm{z}$ 227, 249 and 265 in the lower panel correspond to 2a and its rearranged isomer $\mathbf{1 0 .}$

The transient radical cations $\mathrm{PhSO} \cdot$ and $\mathrm{CH}_{3} \mathrm{CH} \cdot \mathrm{CO}_{2} \mathrm{CH}_{2} \mathrm{CH}_{3}$ (neither as $\mathrm{H}^{+}, \mathrm{Na}^{+}$nor $\mathrm{K}^{+}$adducts) could not be identified in the ESI mass spectrum directly. However, monitoring the advance of the 2a conversion to methylacrylate and the rearranged product $\mathbf{1 0}$ was possible by ESI-MS, provided that both $\mathbf{2 a}$ and $\mathbf{1 0}$ isomers at $\mathrm{m} / \mathrm{z}=249$ displayed distinctive unimolecular dissociation upon collision-induced dissociation (CID) conditions. CID spectra of the sodium adducts of $\mathbf{2 a}$ and $\mathbf{1 0}$ are shown in Figure 2 which allowed us to monitor the temporal evolution of the species.
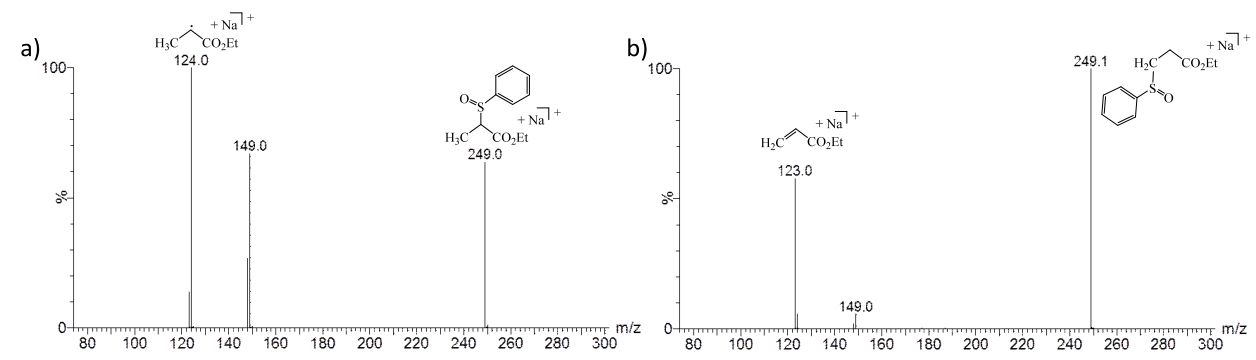

Figure 2. CID spectra of mass-selected species at a) $\mathrm{m} / \mathrm{z}=249[\mathbf{2 a}+\mathrm{Na}]^{+}$and b) $\mathrm{m} / \mathrm{z}=249\left[\mathbf{1 0}+\mathrm{Na}^{+}\left(\mathrm{E}_{\text {laboratory }}=\right.\right.$ $15 \mathrm{eV})$ 
Also helpful is the use of the MS/MS technique, where the fragment spectrum gives direct information about structural aspects of the investigated ion and can provide efficient information about mechanistic properties. It is remarkable that species $[\mathbf{2 a}+\mathrm{Na}]^{+}(\mathrm{m} / \mathrm{z}=249)$ dissociated predominantly via homolytic C-S bond cleavage affording the radical species $\left[\mathrm{CH}_{3} \mathrm{CH} \cdot \mathrm{CO}_{2} \mathrm{CH}_{2} \mathrm{CH}_{3}+\mathrm{Na}\right]^{+}(\mathrm{m} / \mathrm{z}=124)$ whereas species $[\mathbf{1 0}+\mathrm{Na}]^{+}(\mathrm{m} / \mathrm{z}=249)$ dissociated via formation of the closed-shell $\left[\mathrm{CH}_{2} \mathrm{CH} \cdot \mathrm{CO}_{2} \mathrm{CH}_{2} \mathrm{CH}_{3}+\mathrm{Na}\right]^{+}(\mathrm{m} / \mathrm{z}=123)$ product ion. Moreover, at identical collision energies, it is clear that species $[\mathbf{2 a}+\mathrm{Na}]^{+}$is significantly easier to dissociate than $[\mathbf{1 0}+\mathrm{Na}]^{+}$ as evidenced by the relative intensity of the formed product ions. The gas-phase behavior of 2a is reminiscent of that observed for heated solutions for which this compound is more prone to homolytically dissociate via S-C bond cleavage.

The same conditions were also used for monitoring the evolution of the reaction of 2-arylsulfinyl esters $\mathbf{2 b}-\mathbf{f}$. It is remarkable that species [2a-f $+\mathrm{Na}]^{+}$unvariably dissociated predominantly via homolytic C-S bond cleavage affording the respective radical species $\left[\mathrm{RCH}_{2} \mathrm{CH} \cdot \mathrm{CO}_{2} \mathrm{X}+\mathrm{Na}\right]^{+}$respectively, as illustrated in Figure 3 for $\mathbf{2 b - f}$. Fragmentation studies were also performed for the 2-arylsulfide esters and 2-arylsulfonyl esters but no radical intermediates were detected in their respective CID spectra. It is known that sulfides and sulfones do not eliminate as easily as sulfoxides. ${ }^{33}$ 

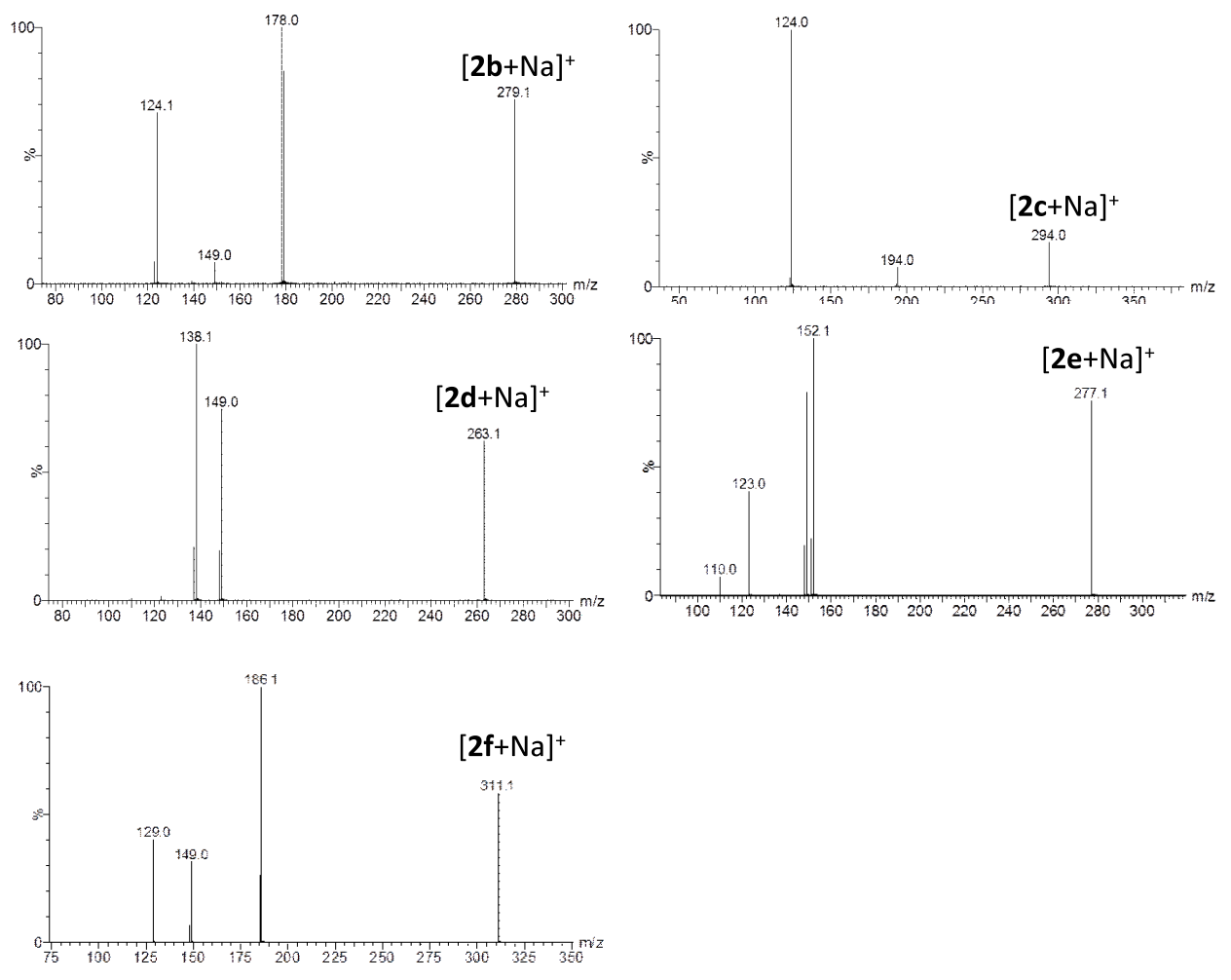

Figure 3. CID spectra of mass-selected species $[\mathbf{2 b - f}+\mathrm{Na}]^{+}$using a collision energy $\left(\mathrm{E}_{\text {laboratory }}\right)=15 \mathrm{eV}$. Radical species detected are $\mathrm{m} / \mathrm{z}=124$ for $\mathbf{2 b}$ and $\mathbf{2 c}, \mathrm{m} / \mathrm{z}=138$ for $\mathbf{2 d}, \mathrm{m} / \mathrm{z}=152$ for $\mathbf{2 e}$ and $\mathrm{m} / \mathrm{z}=186$ for $\mathbf{2 f}$.

The formation of rearrangement products during the elimination of a 2-arylsulfinyl ester was also observed during the synthesis of the natural product $\mathbf{1 8}$ starting from sulfoxide $17 .{ }^{9}$ In this case, 3 -arylsulfonyl lactone $\mathbf{1 9}$ was obtained as a minor product along with the expected $\alpha$-methylene $\gamma$-butyrolactone 18 (Scheme 7) when the reaction was performed in open air. Sulfone $\mathbf{1 9}$ was formed in a highly stereoselective fashion as judged by single-crystal Xray diffraction methods (see Figure S4). ${ }^{34}$ In this case sulfone $\mathbf{1 9}$ was formed instead of the expected sulfoxide, following the well-known tendency of $\gamma$-hydroxy sulfides to be oxidized to sulfones instead of sulfoxides under photooxidation conditions. ${ }^{35}$

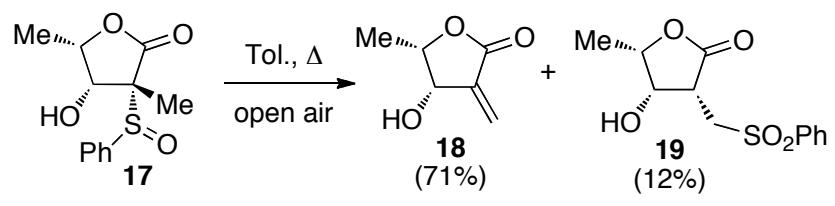


Scheme 7. Synthesis of compounds 18 and 19.

In summary, the mechanism of the dehydrosulfenylation of 2-arylsulfinyl esters for furnishing enoates has been determined to be a homolytic process. The interception of the radical intermediate using a nitroxyl radical and ESI-MS and ESI tandem MS techniques were useful for drawing a comprehensive picture of the intermediates involved in the dehydrosulfenylation of 2-arylsulfinyl esters and suggest that a radical-mediated process is operative. An unprecedented transformation of 2-arylsulfinyl esters to 3-arylsulfinyl esters is also observed as a side reaction whose intimate mechanism is proposed.

\section{Experimental Section}

General Experimental Methods. All solvents used in reactions were freshly distilled from appropriate drying agents

before use. ${ }^{1} \mathrm{H}$ NMR spectra and ${ }^{13} \mathrm{C}$ NMR spectra were measured in $\mathrm{CDCl}_{3}\left({ }^{1} \mathrm{H}, 7.24 \mathrm{ppm} ;{ }^{13} \mathrm{C} 77.0\right.$ ppm $)$ solution at $30{ }^{\circ} \mathrm{C}$ on a $300 \mathrm{MHz}$ or a $500 \mathrm{MHz} \mathrm{NMR}$ spectrometer. IR spectra were recorded as oil films or $\mathrm{KBr}$ discs or $\mathrm{NaCl}$ pellets on a FT-IR spectrometer. EM Science Silica Gel 60 was used for column chromatography while TLC was performed with precoated plates (Kieselgel $60, \mathrm{~F}_{254}, 0.25 \mathrm{~mm}$ ). Unless otherwise specified, all reactions were carried out under argon atmosphere with magnetic stirring.

\section{Electrospray ionization mass spectrometry (ESI-MS) and electron impact mass spectrometry (EI-MS)}

For the on-line reaction monitoring, ESI mass spectra were recorded using an ESI tandem mass spectrometer (quadrupole-hexapole-quadrupole). The drying gas was nitrogen. The temperature of the source block was set to 120 ${ }^{\circ} \mathrm{C}$ and the desolvation temperature to $150{ }^{\circ} \mathrm{C}$. A capillary voltage of $3.5 \mathrm{kV}$ was used in the positive scan mode and the cone voltage $\left(\mathrm{U}_{\mathrm{c}}\right)$ was set to $15 \mathrm{~V}$ to control the extent of fragmentation of the identified ions. Toluene solutions of 2a-f were heated at $100{ }^{\circ} \mathrm{C}$ in an open vial, a drop of the solution was immediately extracted, diluted in hot $\mathrm{CH}_{3} \mathrm{CN}$ and a positive-ion mass spectrum collected. For CID experiments, the cations of interest were mass-selected using the first quadrupole (Q1) and interacted with argon in the hexapole collision cell at variable collision energies (typically 
in the $\mathrm{E}_{\text {laboratory }}=3-10 \mathrm{eV}$ range) while mass analyzing the products with the second analyser. The isolation width was ca. $1 \mathrm{Da}$ and argon was used as a collision gas to produce a pressure of $8 \times 10^{-4} \mathrm{mbar}$.

For accurate $\mathrm{m} / \mathrm{z}$ determinations (for all the compounds except for 16) and CID experiments, an ESI tandem mass spectrometer (quadrupole-Twave-time of flight) was used. The drying gas was nitrogen. The temperature of the source block was set to $120^{\circ} \mathrm{C}$ and the desolvation temperature to $150{ }^{\circ} \mathrm{C}$. A capillary voltage of $3.5 \mathrm{kV}$ was used in the positive scan mode and the cone voltage was set to a low value to control the extent of fragmentation (typically 15 V). Methanol sample solutions were infused via syringe pump directly connected to the ESI source at a flow rate of $10 \mu \mathrm{L} / \mathrm{min}$. Mass calibration was performed using a mixture of $\mathrm{NaOH} 0.05 \mathrm{M}$ : formic acid $10 \%(50: 50)$ from $\mathrm{m} / \mathrm{z} 50$ to 900 . For the accurate mass measurements, a solution of leucine enkephalin $(\mathrm{m} / \mathrm{z}=556.2771)$ was introduced via the lock spray needle at a flow rate of $30 \mu \mathrm{L} / \mathrm{min}$.

For an accurate $\mathrm{m} / \mathrm{z}$ determination of compound 16, a GC-EIMS was used. The GC instrumentation used was equipped with an autosampler, coupled to a TOF mass spectrometer operating in electron ionization (EI) mode. The GC separation was performed using a fused silica column (30 m x $0.25 \mathrm{~mm}$ i.d., $0.25 \mathrm{~mm}$ film thickness). The oven temperature was programmed as follows: $90^{\circ} \mathrm{C}$ (hold $1 \mathrm{~min}$ ); $10^{\circ} \mathrm{C} / \mathrm{min}$ to $300{ }^{\circ} \mathrm{C}$ (hold $2 \mathrm{~min}$ ). The total running time was $24 \mathrm{~min}$. Splitless injections of $1 \mathrm{~mL}$ of sample extracts were carried out with an injector temperature of 300 ${ }^{\circ} \mathrm{C}$ and with a splitless time of $1 \mathrm{~min}$. Helium $99.999 \%$ was used as carrier gas at a constant flow of $1 \mathrm{~mL} / \mathrm{min}$. The interface and ion source temperatures were set to $260{ }^{\circ} \mathrm{C}$ and $250{ }^{\circ} \mathrm{C}$, respectively. A solvent delay of 3 min was used to prevent damage in the ion source filament. TOF MS was operated at an scan time of $0.95 \mathrm{~s}$ in the mass range $m / z$ 60-300 and using a multi-channel plate voltage of $2700 \mathrm{~V}$. TOF MS resolution was about 8500 (FWHM) at $m / z 614$. Pure PFTBA (Perfluorotri-n-butylamine), used for the daily mass calibration/verification as well as for lock mass, was injected via syringe $(\sim 1 \mathrm{~mL})$ in the reference reservoir at $30^{\circ} \mathrm{C}$. The $\mathrm{m} / z$ monitored was 218.9856 .

\section{X-ray crystallography}

Crystals of compound $\mathbf{1 9}$ are air stable and were mounted on the tip of a glass fiber with the use of epoxi cement. Xray diffraction experiment was carried out on a diffractometer using Mo-K $\alpha$ radiation $(\lambda=0.71073 \AA)$ at room 
temperature. The data were collected with a frame width of $0.3^{\circ}$ in $\omega$ and a counting time of $60 \mathrm{~s}$ per frame at a crystal to detector distance of $4 \mathrm{~cm}$. The diffraction frames were integrated using the SAINT package and corrected for absorption with SADABS. The structures were solved by direct methods and refined by the full-matrix method based on $\mathrm{F}^{2}$ using the SHELXTL software package. All non hydrogen atoms were refined anisotropically. Hydrogen atoms were generated geometrically, assigned isotropic thermal parameters and allowed to ride on their respective parent carbon atoms. Crystal data and structure refinement for 19: Empirical formula $\mathrm{C}_{12} \mathrm{H}_{14} \mathrm{O}_{5} \mathrm{~S}$; Crystal system

Monoclinic; Space group P2(1); unit cell dimensions $\mathrm{a}=4.8321(7) \AA, \mathrm{b}=21.157(3) \AA, \mathrm{c}=6.4661(9) \AA, \beta=$ $95.816(3)^{\circ} ; Z=2$; theta range for data collection 1.93 to $30.49^{\circ}$; reflections collected 5373 ; independent reflections $3114[\mathrm{R}(\mathrm{int})=0.0247]$; goodness-of-fit on $\mathrm{F}^{2}=1.030$; Final $\mathrm{R}$ indices $[\mathrm{I}>2$ sigma $(\mathrm{I})] \mathrm{R} 1=0.0424, \mathrm{wR} 2=0.0928 ; \mathrm{R}$ indices (all data) $\mathrm{R} 1=0.0685$, wR2 $=0.1034$; absolute structure parameter $-0.03(8)$; largest diff. peak and hole 0.268 and -0.180 e. $\AA^{-3}$

\section{General experimental procedure for the preparation of thioethers 1a-f:}

To an ice-bath cold solution of sodium hydride (1.85 g, $46.2 \mathrm{mmol})(60 \%$ in mineral oil) in tetrahydrofuran $(110 \mathrm{~mL})$ was added drop wise the corresponding thiophenol $(92.4 \mathrm{mmol})$. The resulting mixture was stirred cold with an icebath for 30 minutes. Then the bromoester $(92.4 \mathrm{mmol})$ was added and the resulting mixture was stirred at room temperature for $72 \mathrm{~h}$. Then was quenched with brine, extracted with ethyl ether $(3 \mathrm{x} 15 \mathrm{~mL})$, and then the organic layers were washed with a saturated aqueous solution of sodium bicarbonate and water, dried $\left(\mathrm{Na}_{2} \mathrm{SO}_{4}\right)$ and concentrated. The crude was purified through chromatography (silica-gel, hexanes/ethyl acetate (95:5)) to afford the desired compound.

Ethyl 2-(phenylthio)propanoate 1a. (yield= $12.61 \mathrm{~g}, 65 \%) .{ }^{1} \mathrm{H} \mathrm{NMR}\left(300 \mathrm{MHz}, \mathrm{CDCl}_{3}\right) \delta$ 7.46-7.48 (2H, m), 7.26$7.32(3 \mathrm{H}, \mathrm{m}), 4.11(2 \mathrm{H}, \mathrm{q}, \mathrm{J}=7.2 \mathrm{~Hz}), 3.78(1 \mathrm{H}, \mathrm{q}, \mathrm{J}=6.9 \mathrm{~Hz}), 1.48(3 \mathrm{H}, \mathrm{d}, \mathrm{J}=6.9 \mathrm{~Hz}), 1.17(3 \mathrm{H}, \mathrm{t}, \mathrm{J}=7.2 \mathrm{~Hz}) .{ }^{13} \mathrm{C}$ NMR (75 MHz, $\left.\mathrm{CDCl}_{3}\right) \delta 173.0,133.4,129.2,128.3,61.5,45.6,17.7,14.3$ ppm. IR (NaCl) $\delta 3060,2981,2933$, $2872,1955,1883,1732,1583,1476,1440,1375,1323,1256,1225,1159,1068,1025,897,859,776,748,691,596$ $\mathrm{cm}^{-1}$. HRMS $m / z$ calcd. for $\mathrm{C}_{11} \mathrm{H}_{14} \mathrm{O}_{2} \mathrm{SNa}\left[\mathrm{M}+\mathrm{Na}^{+}\right]: 233.0612$, found: 233.0611. 
Ethyl 2-((4-methoxyphenyl)thio)propanoate 1b. (yield= $13.3 \mathrm{~g}, 60 \%) .{ }^{1} \mathrm{H} \mathrm{NMR}\left(500 \mathrm{MHz}, \mathrm{CDCl}_{3}\right) \delta 7.36(2 \mathrm{H}, \mathrm{d}$, $\mathrm{J}=8.0 \mathrm{~Hz}), 6.79(2 \mathrm{H}, \mathrm{d}, \mathrm{J}=8.5 \mathrm{~Hz}), 4.06(2 \mathrm{H}, \mathrm{q}, \mathrm{J}=7.0 \mathrm{~Hz}), 3.75(3 \mathrm{H}, \mathrm{s}), 3.57(1 \mathrm{H}, \mathrm{q}, \mathrm{J}=7.0 \mathrm{~Hz}), 1.37(3 \mathrm{H}, \mathrm{d}, \mathrm{J}=$ 7.0Hz), $1.14(3 \mathrm{H}, \mathrm{t}, \mathrm{J}=7.5 \mathrm{~Hz}) .{ }^{13} \mathrm{C} \mathrm{NMR}\left(75 \mathrm{MHz}, \mathrm{CDCl}_{3}\right) \delta 172.9,160.5,136.7,123.4,114.7,61.2,55.5,46.2$, 17.4, 14.3 ppm. IR $(\mathrm{NaCl}) \delta 2927,1727,1591,1493,1461,1286,1247,1172,1029,827 \mathrm{~cm}^{-1} . \mathrm{HRMS} \mathrm{m} / z$ calcd. for $\mathrm{C}_{12} \mathrm{H}_{16} \mathrm{O}_{3} \mathrm{SNa}\left[\mathrm{M}+\mathrm{Na}^{+}\right]: 263.0718$, found: 263.0712 .

Ethyl 2-((4-nitrophenyl)thio)propanoate 1c. (yield= $12.25 \mathrm{~g}, 52 \%) .{ }^{1} \mathrm{H} \mathrm{NMR}\left(500 \mathrm{MHz}, \mathrm{CDCl}_{3}\right) \delta 8.11(2 \mathrm{H}, \mathrm{d}, \mathrm{J}=$ 8.5Hz), $7.46(2 \mathrm{H}, \mathrm{d}, \mathrm{J}=9.0 \mathrm{~Hz}), 4.15(2 \mathrm{H}, \mathrm{m}), 4.00(2 \mathrm{H}, \mathrm{q}, \mathrm{J}=7.0 \mathrm{~Hz}), 1.56(3 \mathrm{H}, \mathrm{d}, \mathrm{J}=7.5 \mathrm{~Hz}), 1.19(3 \mathrm{H}, \mathrm{t}, \mathrm{J}=7.0 \mathrm{~Hz})$. ${ }^{13} \mathrm{C}$ NMR $\left(125 \mathrm{MHz}, \mathrm{CDCl}_{3}\right) \delta 172.2,144.9,131.5,129.3,124.3,62.1,44.1,17.6,14.4 \mathrm{ppm} . \mathrm{IR}(\mathrm{NaCl}) \delta 2925$ $1732,1596,1578,1515,1477,1341,1259,1174,1076,1013,853,742,683 \mathrm{~cm}^{-1}$. HRMS m/z calcd. for $\mathrm{C}_{11} \mathrm{H}_{14} \mathrm{NO}_{4} \mathrm{~S}$ [M+H $\mathrm{H}^{+}$]: 256.0644, found: 256.0647; calcd. for $\mathrm{C}_{11} \mathrm{H}_{13} \mathrm{NO}_{4} \mathrm{SNa}\left[\mathrm{M}+\mathrm{Na}^{+}\right]$: 278.0463, found: 278.0464 .

Ethyl 2-(phenylthio)butanoate 1d. (yield= $19.25 \mathrm{~g}, 93 \%) .{ }^{1} \mathrm{H} \mathrm{NMR}\left(300 \mathrm{MHz}, \mathrm{CDCl}_{3}\right) \delta 7.44(2 \mathrm{H}, \mathrm{m}), 7.25(3 \mathrm{H}$, m), $4.09(2 \mathrm{H}, \mathrm{dq}, \mathrm{J}=1.2,7.2 \mathrm{~Hz}), 3.56(1 \mathrm{H}, \mathrm{dd}, \mathrm{J}=6.6,8.4 \mathrm{~Hz}), 1.70-1.95(\mathrm{~m}, 2 \mathrm{H}), 1.15(3 \mathrm{H}, \mathrm{t}, \mathrm{J}=6.9 \mathrm{~Hz}), 1.09(3 \mathrm{H}, \mathrm{t}$, $\mathrm{J}=7.2 \mathrm{~Hz}) .{ }^{13} \mathrm{C} \mathrm{NMR}\left(75 \mathrm{MHz}, \mathrm{CDCl}_{3}\right) \delta 172.0,133.7,132.7,128.8,127.7,60.9,52.4,25.1,14.0,11.7$ ppm. IR (oil) $\delta 3079,2970,2936,2877,1959,1884,1735,1583,1480,1443,1368,1343,1300,1234,1209,1160,1091,1026$, 941, 864, $811 \mathrm{~cm}^{-1}$. HRMS m/z calcd. for $\mathrm{C}_{12} \mathrm{H}_{17} \mathrm{O}_{2} \mathrm{~S}\left[\mathrm{M}+\mathrm{H}^{+}\right]$: 225.0949, found: 225.0953; calcd. for $\mathrm{C}_{12} \mathrm{H}_{16} \mathrm{O}_{2} \mathrm{SNa}$ $\left[\mathrm{M}+\mathrm{Na}^{+}\right]: 247.0769$, found: 247.0772 .

Ethyl 2-(phenylthio)pentanoate 1e. (yield= $19.35 \mathrm{~g}, 88 \%) .{ }^{1} \mathrm{H} \mathrm{NMR}\left(300 \mathrm{MHz}, \mathrm{CDCl}_{3}\right) \delta$ 7.43-7.47 (2H, m), 7.24$7.31(3 \mathrm{H}, \mathrm{m}), 4.10(2 \mathrm{H}, \mathrm{q}, \mathrm{J}=7.2 \mathrm{~Hz}), 3.65(1 \mathrm{H}, \mathrm{dd}, \mathrm{J}=6.6,8.1 \mathrm{~Hz}), 1.67-1.94(\mathrm{~m}, 2 \mathrm{H}), 1.38-1.52(\mathrm{~m}, 2 \mathrm{H}), 1.15(3 \mathrm{H}, \mathrm{t}$, $\mathrm{J}=6.6 \mathrm{~Hz}), 0.92(3 \mathrm{H}, \mathrm{t}, \mathrm{J}=7.2 \mathrm{~Hz}) .{ }^{13} \mathrm{C} \mathrm{NMR}\left(75 \mathrm{MHz}, \mathrm{CDCl}_{3}\right) \delta 172.0,133.7,132.7,128.7,127.6,60.7,50.5,33.7$, 20.5, 14.0, 13.6 ppm. IR (oil) $\delta 3066,2968,2936,2876,1958,1884,1733,1585,1483,1444,1374,1335,1303$, $1279,1243,1163,1106,1033,934,860,808 \mathrm{~cm}^{-1}$. HRMS m/z calcd. for $\mathrm{C}_{13} \mathrm{H}_{19} \mathrm{O}_{2} \mathrm{~S}\left[\mathrm{M}+\mathrm{H}^{+}\right]$: 239.1106, found: 239.1115; calcd. for $\mathrm{C}_{13} \mathrm{H}_{18} \mathrm{O}_{2} \mathrm{SNa}\left[\mathrm{M}+\mathrm{Na}^{+}\right]$: 261.0925, found: 261.0923 .

Benzyl 2-(phenylthio)propanoate 1f. (yield= $17.59 \mathrm{~g}, 70 \%) .{ }^{1} \mathrm{H} \mathrm{NMR}\left(300 \mathrm{MHz}, \mathrm{CDCl}_{3}\right) \delta$ 7.24-7.44 (10H, m), $5.11(2 \mathrm{H}, \mathrm{s}), 3.85(1 \mathrm{H}, \mathrm{d}, \mathrm{J}=7.2 \mathrm{~Hz}), 1.52(3 \mathrm{H}, \mathrm{d}, \mathrm{J}=7.2 \mathrm{~Hz}) .{ }^{13} \mathrm{C} \mathrm{NMR}\left(75 \mathrm{MHz}, \mathrm{CDCl}_{3}\right) \delta 172.5,135.5,133.2$

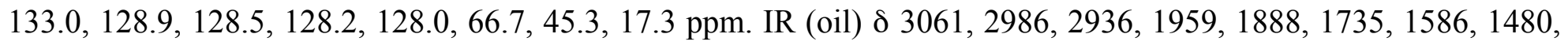


$1443,1380,1324,1268,1162,1063,1029,1004,954,898,780 \mathrm{~cm}^{-1}$. HRMS $\mathrm{m} / z$ calcd. for $\mathrm{C}_{16} \mathrm{H}_{17} \mathrm{O}_{2} \mathrm{~S}\left[\mathrm{M}+\mathrm{H}^{+}\right]$: 273.0949, found: 273.0946; calcd. for $\mathrm{C}_{16} \mathrm{H}_{16} \mathrm{O}_{2} \mathrm{SNa}\left[\mathrm{M}+\mathrm{Na}^{+}\right]$: 295.0769, found: 295.0770.

\section{General experimental procedure for the preparation of sulfoxides 2a-f:}

To a $-10^{\circ} \mathrm{C}$ cold solution of thioether $(0.95 \mathrm{mmol})$ in $\mathrm{CH}_{2} \mathrm{Cl}_{2}(5 \mathrm{~mL})$ was added a solution of $m$-CPBA (77\% pure) (177 mg, $0.79 \mathrm{mmol})$ in $\mathrm{CH}_{2} \mathrm{Cl}_{2}(4 \mathrm{~mL})$. The resulting mixture was stirred at $-10^{\circ} \mathrm{C}$ for $30 \mathrm{~min}$ and then was quenched with saturated aqueous solution of sodium bicarbonate, extracted with $\mathrm{CH}_{2} \mathrm{Cl}_{2}(3 \times 15 \mathrm{~mL})$, and then the organic layers were sequently washed with brine and saturated aqueous solution of sodium bicarbonate and water, dried $\left(\mathrm{Na}_{2} \mathrm{SO}_{4}\right)$ and concentrated. The crude was purified through chromatography (silica-gel, hexanes/ethyl acetate (7:3)) to afford the desired sulfoxide.

Ethyl 2-(phenylsulfinyl)propanoate 2a. (yield= $178 \mathrm{mg}, 83 \%) .{ }^{1} \mathrm{H} \mathrm{NMR}\left(500 \mathrm{MHz}, \mathrm{CDCl}_{3}\right) \delta$ 7.25-7.45 (5H, m) (major and minor), $4.12(2 \mathrm{H}, \mathrm{m})$ (major and minor), $3.81(1 \mathrm{H}, \mathrm{q}, \mathrm{J}=6.5 \mathrm{~Hz})$ (major), $3.49(1 \mathrm{H}, \mathrm{q}, \mathrm{J}=7.0 \mathrm{~Hz})($ minor), $1.49(3 \mathrm{H}, \mathrm{d}, \mathrm{J}=7.0 \mathrm{~Hz})$ (major), $1.32(3 \mathrm{H}, \mathrm{d}, \mathrm{J}=7.5 \mathrm{~Hz})($ minor), $1.21(3 \mathrm{H}, \mathrm{t}, \mathrm{J}=6.5 \mathrm{~Hz})($ minor), $1.18(3 \mathrm{H}, \mathrm{t}, \mathrm{J}=7.0 \mathrm{~Hz})$ (major). ${ }^{13} \mathrm{C}$ NMR $\left(125 \mathrm{MHz}, \mathrm{CDCl}_{3}\right) \delta 168.9,168.1,142.6,140.9,134.5,132.1,131.9,129.7,129.5,129.3,125.5$, 125.1, 66.2, 64.1, 62.1, 62.0, 14.3, 14.2, 10.0, 9.1 ppm. IR (NaCl) $\delta 3051,2988,2926,1968,1895,1724,1577,1472$, $1445,1371,1316,1254,1215,1165,1083,1045,1017,920,889,858,749,691 \mathrm{~cm}^{-1}$. HRMS $\mathrm{m} / z$ calcd. for $\mathrm{C}_{11} \mathrm{H}_{14} \mathrm{O}_{3} \mathrm{SNa}\left[\mathrm{M}+\mathrm{Na}^{+}\right]: 249.0556$, found: 249.0557 .

Ethyl 2-((4-methoxyphenyl)sulfinyl)propanoate 2 b. (yield= $124 \mathrm{mg}, 51 \%) .{ }^{1} \mathrm{H} \mathrm{NMR}\left(500 \mathrm{MHz}, \mathrm{CDCl}_{3}\right) \delta 7.56$ $(2 \mathrm{H}, \mathrm{d}, \mathrm{J}=8.5 \mathrm{~Hz})$ (major), $7.52(2 \mathrm{H}, \mathrm{d}, \mathrm{J}=8.5 \mathrm{~Hz})$ (minor), $7.00(2 \mathrm{H}, \mathrm{d}, \mathrm{J}=8.5 \mathrm{~Hz})$ (major and minor), 4.04-4.20 (2H, m) (major and minor), $3.85(3 \mathrm{H}, \mathrm{s})$ (major and minor), $3.78(1 \mathrm{H}, \mathrm{q}, \mathrm{J}=7.0 \mathrm{~Hz})$ (major), $3.47(1 \mathrm{H}, \mathrm{q}, \mathrm{J}=8.0 \mathrm{~Hz})$ (minor), $1.50(3 \mathrm{H}, \mathrm{d}, \mathrm{J}=7.0 \mathrm{~Hz})$ (major), $1.27(3 \mathrm{H}, \mathrm{d}, \mathrm{J}=7.0 \mathrm{~Hz})$ (minor), $1.23(3 \mathrm{H}, \mathrm{t}, \mathrm{J}=7.0 \mathrm{~Hz})$ (minor), $1.15(3 \mathrm{H}, \mathrm{t}$, $\mathrm{J}=7.0 \mathrm{~Hz})$ (major). ${ }^{13} \mathrm{C} \mathrm{NMR}\left(125 \mathrm{MHz}, \mathrm{CDCl}_{3}\right) \delta 169.1,168.3,162.7,133.2,131.5,127.3,126.9,114.9,114.8,66.3$, 64.3, 61.9, 55.8, 14.3, 14.3, 10.4, 8.9 ppm. IR (KBr) $\delta 3096,3069,2981,2940,2842,1727,1598,1500,1459,1306$, 1258, 1173, 1092, 1024, 834, 793, $626 \mathrm{~cm}^{-1}$. HRMS $\mathrm{m} / \mathrm{z}$ calcd. for $\mathrm{C}_{12} \mathrm{H}_{17} \mathrm{O}_{4} \mathrm{~S}\left[\mathrm{M}+\mathrm{H}^{+}\right]: 257.0848$, found: 257.0849; calcd. for $\mathrm{C}_{12} \mathrm{H}_{16} \mathrm{O}_{4} \mathrm{SNa}\left[\mathrm{M}+\mathrm{Na}^{+}\right]$: 279.0667, found: 279.0656 . 
Ethyl 2-((4-nitrophenyl)sulfinyl)propanoate 2c. (yield= $160 \mathrm{mg}, 62 \%) .{ }^{1} \mathrm{H} \mathrm{NMR}\left(500 \mathrm{MHz}, \mathrm{CDCl}_{3}\right) \delta 8.31(2 \mathrm{H}, \mathrm{d}$, $\mathrm{J}=8.5 \mathrm{~Hz}$ ) (major), $8.30(2 \mathrm{H}, \mathrm{d}, \mathrm{J}=9.0 \mathrm{~Hz})($ minor), $7.82(2 \mathrm{H}, \mathrm{d}, \mathrm{J}=9.0 \mathrm{~Hz})$ (major), $7.77(2 \mathrm{H}, \mathrm{d}, \mathrm{J}=9.0 \mathrm{~Hz})(\mathrm{minor})$, 4.04-4.15 $(2 \mathrm{H}, \mathrm{m})$ (major and minor), $3.84(1 \mathrm{H}, \mathrm{q}, \mathrm{J}=7.0 \mathrm{~Hz})$ (major), $3.48(1 \mathrm{H}, \mathrm{q}, \mathrm{J}=7.0 \mathrm{~Hz})(\operatorname{minor}), 1.41(3 \mathrm{H}, \mathrm{d}, \mathrm{J}=$ 7.5Hz) (major), $1.30(3 \mathrm{H}, \mathrm{d}, \mathrm{J}=7.0 \mathrm{~Hz})$ (minor), $1.17(3 \mathrm{H}, \mathrm{t}, \mathrm{J}=7.5 \mathrm{~Hz})$ (minor), $1.15(3 \mathrm{H}, \mathrm{t}, \mathrm{J}=7.5 \mathrm{~Hz})(\mathrm{major}) .{ }^{13} \mathrm{C}$ NMR $\left(125 \mathrm{MHz}, \mathrm{CDCl}_{3}\right) \delta 169.6,168.3,149.7,147.9,126.6,126.2,127.3,125.6,125.0,65.6,63.7,62.5,62.3,14.2$, 9.4, 9.0 ppm. IR $(\mathrm{NaCl}) \delta 3101,2985,1732,1603,1579,1527,1475,1450,1398,1347,1150,1089,1054,1011$, 1017, 853, 743, 723, $684 \mathrm{~cm}^{-1}$. HRMS $m / z$ calcd. for $\mathrm{C}_{11} \mathrm{H}_{14} \mathrm{NO}_{5} \mathrm{~S}\left[\mathrm{M}+\mathrm{H}^{+}\right]: 272.0593$, found: 272.0580; calcd. for $\mathrm{C}_{11} \mathrm{H}_{13} \mathrm{NO}_{5} \mathrm{SNa}\left[\mathrm{M}+\mathrm{Na}^{+}\right]$: 294.0412, found: 294.0405.

Ethyl 2-(phenylsulfinyl)butanoate 2d. (yield= $187 \mathrm{mg}, 82 \%) .{ }^{1} \mathrm{H}$ NMR $\left(500 \mathrm{MHz}, \mathrm{CDCl}_{3}\right) \delta 7.49-7.66(5 \mathrm{H}, \mathrm{m})$ (major and minor), 3.95-4.10 (2H, m) (major and minor), $3.48(1 \mathrm{H}, \mathrm{dd}, \mathrm{J}=5.0,10.0 \mathrm{~Hz})(\mathrm{major}), 3.39(1 \mathrm{H}, \mathrm{dd}, \mathrm{J}=5.0$, 9.5Hz) (minor), 2.06-2.16 (1H, m) (major and minor), 1.76-1.90 $(1 \mathrm{H}, \mathrm{m})$ (major and minor), $1.12(3 \mathrm{H}, \mathrm{t}, \mathrm{J}=7.5 \mathrm{~Hz})$ (major), $1.06(3 \mathrm{H}, \mathrm{t}, \mathrm{J}=7.5 \mathrm{~Hz})$ (minor), $1.03(3 \mathrm{H}, \mathrm{t}, \mathrm{J}=7.0 \mathrm{~Hz})$ (major), $1.00(3 \mathrm{H}, \mathrm{t}, \mathrm{J}=7.5 \mathrm{~Hz})$ (minor). ${ }^{13} \mathrm{C} \mathrm{NMR}(125$ $\left.\mathrm{MHz}, \mathrm{CDCl}_{3}\right) \delta 167.6,166.7,142.2,141.1,131.7,131.4,129.9,128.9,124.8,124.7,73.5,70.6,61.3,20.3,18.7$ 13.8, 11.5, 11.3 ppm. IR (oil) $\delta 3066,2975,2940,2880,2088,1972,1894,1726,1638,1581,1476,1448,1374$, $1335,1258,1202,1163,1089,1039,952,860,815 \mathrm{~cm}^{-1}$. HRMS $\mathrm{m} / z$ calcd. for $\mathrm{C}_{12} \mathrm{H}_{17} \mathrm{O}_{3} \mathrm{~S}\left[\mathrm{M}+\mathrm{H}^{+}\right]: 241.0898$, found: 241.0900; calcd. for $\mathrm{C}_{12} \mathrm{H}_{16} \mathrm{O}_{3} \mathrm{SNa}\left[\mathrm{M}+\mathrm{Na}^{+}\right]$: 263.0718, found: 263.0722 .

Ethyl 2-(phenylsulfinyl)pentanoate 2e. (yield= $222 \mathrm{mg}, 92 \%) .{ }^{1} \mathrm{H} \mathrm{NMR}\left(500 \mathrm{MHz}, \mathrm{CDCl}_{3}\right) \delta 7.46-7.65(5 \mathrm{H}, \mathrm{m})$ (major and minor), 3.88-4.10 (2H, m) (major and minor), $3.53(1 \mathrm{H}, \mathrm{dd}, \mathrm{J}=5.5,10.0 \mathrm{~Hz})(\mathrm{major}), 3.43(1 \mathrm{H}, \mathrm{dd}, \mathrm{J}=5.0$, $9.0 \mathrm{~Hz})$ (minor), 2.02-2.10 $(1 \mathrm{H}, \mathrm{m})$ (major and minor), 1.73-1.84 $(1 \mathrm{H}, \mathrm{m})$ (major and minor), 1.28-1.48 $(2 \mathrm{H}, \mathrm{m})$ (major and minor), $1.09(3 \mathrm{H}, \mathrm{t}, \mathrm{J}=7.0 \mathrm{~Hz})$ (major), $1.03(3 \mathrm{H}, \mathrm{t}, \mathrm{J}=7.5 \mathrm{~Hz})$ (minor), $0.91(3 \mathrm{H}, \mathrm{t}, \mathrm{J}=7.0 \mathrm{~Hz})($ major), 0.88 $(3 \mathrm{H}, \mathrm{t}, \mathrm{J}=7.5 \mathrm{~Hz})$ (minor). ${ }^{13} \mathrm{C} \mathrm{NMR}\left(125 \mathrm{MHz}, \mathrm{CDCl}_{3}\right) \delta 167.9,166.8,142.3,141.7,131.7,131.5,129.0,128.8$

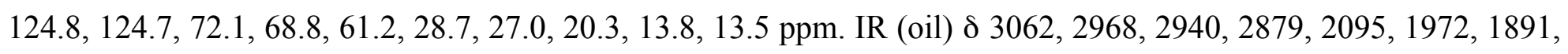
$1729,1585,1469,1447,1377,1335,1275,1247,1191,1156,1089,1057,941,860,825 \mathrm{~cm}^{-1} . \mathrm{HRMS} \mathrm{m} / z$ calcd. for $\mathrm{C}_{13} \mathrm{H}_{19} \mathrm{O}_{3} \mathrm{~S}\left[\mathrm{M}+\mathrm{H}^{+}\right.$]: 255.1055, found: 255.1053; calcd. for $\mathrm{C}_{13} \mathrm{H}_{18} \mathrm{O}_{3} \mathrm{SNa}\left[\mathrm{M}+\mathrm{Na}^{+}\right]$: 277.0874, found: 277.0876 . 
Benzyl 2-(phenylsulfinyl)propanoate 2f. (yield= $192 \mathrm{mg}, 70 \%) .{ }^{1} \mathrm{H} \mathrm{NMR}\left(300 \mathrm{MHz}, \mathrm{CDCl}_{3}\right) \delta$ 7.17-7.55 (10H, m)

(major and minor), $5.10(1 \mathrm{H}, \mathrm{d}, \mathrm{J}=12.0 \mathrm{~Hz})$ (major), $5.10(1 \mathrm{H}, \mathrm{d}, \mathrm{J}=12.0 \mathrm{~Hz})$ (minor), $5.00(1 \mathrm{H}, \mathrm{d}, \mathrm{J}=12.0 \mathrm{~Hz})$ (major), $4.99(1 \mathrm{H}, \mathrm{d}, \mathrm{J}=12.0 \mathrm{~Hz})$ (minor), $3.82(1 \mathrm{H}, \mathrm{q}, \mathrm{J}=7.2 \mathrm{~Hz}$ ) (major), $3.50(1 \mathrm{H}, \mathrm{q}, \mathrm{J}=7.2 \mathrm{~Hz})($ minor), $1.41(3 \mathrm{H}, \mathrm{d}$, $\mathrm{J}=6.9 \mathrm{~Hz})$ (major), $1.26(3 \mathrm{H}, \mathrm{d}, \mathrm{J}=7.2 \mathrm{~Hz})$ (minor). ${ }^{13} \mathrm{C} \mathrm{NMR}\left(75 \mathrm{MHz}, \mathrm{CDCl}_{3}\right) \delta 168.4,167.5,142.0,140.2,134.9$, $131.7,131.5,129.1,128.9,128.6,128.5,128.4,128.3,125.0,124.6,67.4,67.3,65.4,63.5,9.4,8.6$ ppm. IR (oil) $\delta$ $3067,3036,2939,1965,1894,1732,1583,1499,1477,1449,1380,1318,1222,1163,1050,998,957,920,848,820$, $777 \mathrm{~cm}^{-1}$. HRMS m/z calcd. for $\mathrm{C}_{16} \mathrm{H}_{17} \mathrm{O}_{3} \mathrm{~S}\left[\mathrm{M}+\mathrm{H}^{+}\right]: 289.0898$, found: 289.0894; calcd. for $\mathrm{C}_{16} \mathrm{H}_{16} \mathrm{O}_{3} \mathrm{SNa}\left[\mathrm{M}+\mathrm{Na}^{+}\right]$: 311.0718, found: 311.0713 .

\section{Experimental procedure for elimination}

A mixture of compound $2(1 \mathrm{mmol})$ in toluene $(6 \mathrm{~mL})$ was heated at $110^{\circ} \mathrm{C}$ for $5 \mathrm{~h}$ (in case of compounds $2 \mathbf{2 a}, \mathbf{2 b}, \mathbf{2 c}$ and $2 \mathbf{f}$ the reaction was performed in a sealed flask to avoid acrylate loss). Then the resulting crude mixture was purified through chromatography (silica-gel, hexanes/ethyl acetate (1:1), (1:2) and ethyl acetate) to afford the corresponding enoate.

$\boldsymbol{S}$-phenyl benzenesulfonothioate $9 .{ }^{1} \mathrm{H} \mathrm{NMR}\left(500 \mathrm{MHz}, \mathrm{CDCl}_{3}\right) \delta 7.13-7.51(10 \mathrm{H}, \mathrm{m}) .{ }^{13} \mathrm{C} \mathrm{NMR}\left(125 \mathrm{MHz}, \mathrm{CDCl}_{3}\right)$ $\delta 143.0,136.6,133.6,131.4,129.4,129.0,128.8,127.9,127.6,127.2$ ppm. IR (NaCl) $\delta 3064,1580,1445,1323$, 1144, 1076, 1021, 748, $688 \mathrm{~cm}^{-1}$. HRMS m/z calcd. for $\mathrm{C}_{12} \mathrm{H}_{10} \mathrm{O}_{2} \mathrm{~S}_{2} \mathrm{Na}\left[\mathrm{M}+\mathrm{Na}^{+}\right]: 273.0020$, found: 273.0026 .

Diphenyl disulfide 16. ${ }^{1} \mathrm{H} \mathrm{NMR}\left(500 \mathrm{MHz}, \mathrm{CDCl}_{3}\right) \delta 7.13-7.17(2 \mathrm{H}, \mathrm{m}), 7.21-7.24(4 \mathrm{H}, \mathrm{t}, \mathrm{J}=8.5 \mathrm{~Hz}), 7.42(4 \mathrm{H}, \mathrm{d}, \mathrm{J}$ $=8.5 \mathrm{~Hz}) \cdot{ }^{13} \mathrm{C} \mathrm{NMR}\left(125 \mathrm{MHz}, \mathrm{CDCl}_{3}\right) \delta 137.1,129.0,127.6,127.2 \mathrm{ppm} . \mathrm{IR}(\mathrm{NaCl}) \delta 3064,1946,1864,1800,1735$, 1574, 1470, 1432, 1379, 1298, 1068, 1017, 896, 787, 735, 686, $605 \mathrm{~cm}^{-1}$. HRMS (EI) $m / z$ calcd. for $\mathrm{C}_{12} \mathrm{H}_{10} \mathrm{~S}_{2}[\mathrm{M}]:$ 218.0224, found: 218.0210 .

2-(Ethoxycarbonyl)ethyl benzenesulfenate 10. ${ }^{1} \mathrm{H} \mathrm{NMR}\left(500 \mathrm{MHz}, \mathrm{CDCl}_{3}\right) \delta$ 7.61-7.62 (2H, m), 7.49-7.54 (3H, $\mathrm{m}), 4.11(2 \mathrm{H}, \mathrm{q}, \mathrm{J}=7.5 \mathrm{~Hz}), 3.22(1 \mathrm{H}, \mathrm{m}), 2.97(1 \mathrm{H}, \mathrm{m}), 2.84(1 \mathrm{H}, \mathrm{m}), 2.54(1 \mathrm{H}, \mathrm{m}), 1.22(3 \mathrm{H}, \mathrm{d}, \mathrm{J}=7.5 \mathrm{~Hz}) .{ }^{13} \mathrm{C} \mathrm{NMR}$ $\left(125 \mathrm{MHz}, \mathrm{CDCl}_{3}\right) \delta 171.5,143.4,131.5,129.6,124.4,61.4,51.5,26.5,14.4$ ppm. IR $(\mathrm{NaCl}) \delta 2963,1733,1445$ 
1373, 1260, 1087, 1045, 799, 750, $691 \mathrm{~cm}^{-1}$. HRMS $m / z$ calcd. for $\mathrm{C}_{11} \mathrm{H}_{14} \mathrm{O}_{3} \mathrm{SNa}\left[\mathrm{M}+\mathrm{Na}^{+}\right]$: 249.0561, found: 249.0561.

\section{Experimental procedure for trapping the radical}

A mixture of compound $2 \mathrm{e}(500 \mathrm{mg}, 1.96 \mathrm{mmol})$ and 2,2,6,6-Tetramethyl-1-piperidinyloxy (Tempo) (614 mg, 3.93 mmol) in toluene $(10 \mathrm{~mL})$ was heated at $80{ }^{\circ} \mathrm{C}$ for $2 \mathrm{~h}$. Then the resulting crude mixture was carefully concentrated under vacuum and then purified through chromatography (silica-gel, hexanes/ethyl acetate (95:5)) to afford compound $\mathbf{1 3}$ ( $17 \mathrm{mg}, 3 \%$ ) as an oil and compound $\mathbf{1 4}(60 \mathrm{mg}, 11 \%$ ) as a white solid. Recrystallization of 14 from $\mathrm{CH}_{2} \mathrm{Cl}_{2} / \mathrm{Hexanes}$ gave white prismatic crystals (m.p. $=128-130{ }^{\circ} \mathrm{C}$ )

Ethyl 2-((2,2,6,6-tetramethylpiperidin-1-yl)oxy)pentanoate 13. ${ }^{1} \mathrm{H}$ NMR $\left(300 \mathrm{MHz}, \mathrm{CDCl}_{3}\right) \delta 4.21(1 \mathrm{H}, \mathrm{dd}, \mathrm{J}=$ 6.6, 7.5 Hz), $4.15(2 \mathrm{H}, \mathrm{q}, \mathrm{J}=7.2 \mathrm{~Hz}), 1.74-1.85(2 \mathrm{H}, \mathrm{m}), 1.01-1.48(23 \mathrm{H}, \mathrm{m}), 0.91(3 \mathrm{H}, \mathrm{t}, \mathrm{J}=7.2 \mathrm{~Hz}) .{ }^{13} \mathrm{C} \mathrm{NMR}(75$ $\left.\mathrm{MHz}, \mathrm{CDCl}_{3}\right) \delta 173.6,85.5,60.1,40.3,34.2,33.6,33.0,20.2,17.9,17.1,14.2,13.9$ ppm. IR (KBr) $\delta 2974,2933$, 2876, 1748, 1466, 1381, 1366, 1269, 1245, 1184, 1133, 1105, 1058, 1031, 993, 976, 963, 929, 881, 857, 793, 752, 722, $681,650 \mathrm{~cm}^{-1}$. HRMS $\mathrm{m} / z$ calcd. for $\mathrm{C}_{16} \mathrm{H}_{32} \mathrm{NO}_{3}\left[\mathrm{M}+\mathrm{H}^{+}\right]$: 286.2382, found: 286.2377 .

2,2,6,6-tetramethylpiperidin-1-yl benzenesulfinate 14. ${ }^{1} \mathrm{H} \mathrm{NMR}\left(300 \mathrm{MHz}, \mathrm{CDCl}_{3}\right) \delta$ 7.82-7.89 $(2 \mathrm{H}, \mathrm{m}), 7.39-7.47$ $(3 \mathrm{H}, \mathrm{m}), 1.66(6 \mathrm{H}, \mathrm{s}), 1.57(12 \mathrm{H}, \mathrm{s}) .{ }^{13} \mathrm{C}$ NMR $\left(75 \mathrm{MHz}, \mathrm{CDCl}_{3}\right) \delta 147.2,131.2,128.5,126.0,60.8,43.8,31.1,16.7$ ppm. IR (KBr) $\delta$ 3069, 3035, 2984, 2944, 2916, 2879, 1404, 1394, 1245, 1204, 1184, 1139, 1095, 1071, 980, 922, 786, 766, 715, 701, 626, $613 \mathrm{~cm}^{-1}$. HRMS $\mathrm{m} / z$ calcd. for $\mathrm{C}_{15} \mathrm{H}_{23} \mathrm{NO}_{2} \mathrm{SNa}\left[\mathrm{M}+\mathrm{Na}^{+}\right]:$304.1347, found: 304.1348 .

\section{(4S,5S)-dihydro-4-hydroxy-5-methyl-3-methylenefuran-2(3H)-}

one (18) and (3R,4S,5S)-dihydro-4-hydroxy-5-methyl-3-((phenylsulfonyl)methyl)furan-2(3H)-one (19). An oxygen-flushed mixture of compound $17(124 \mathrm{mg}, 0.48 \mathrm{mmol})$ in toluene $(8 \mathrm{~mL})$ was heated at $110{ }^{\circ} \mathrm{C}$ for $5 \mathrm{~h}$. Then the solvent was removed under vacuum and the resulting mixture was purified through chromatography (silica-gel, hexanes/ethyl acetate (1:1), (1:2) and ethyl acetate) to afford $44 \mathrm{mg}$ (71\%) of compound $\mathbf{1 8}$ as a colorless oil and 16 mg (12\%) of compound 19 as a white solid. Recrystallization from $\mathrm{CHCl}_{3} / \mathrm{Hexanes}$ gave white needles $(\mathrm{mp}=117$ - 
$\left.120^{\circ} \mathrm{C}\right)$.

Spectroscopic data of 18: $[\alpha]_{20}{ }^{\mathrm{D}}=-97.26\left(\mathrm{c}=1.3, \mathrm{CHCl}_{3}\right) .{ }^{1} \mathrm{H}$ NMR $\left(300 \mathrm{MHz}, \mathrm{CDCl}_{3}\right) \delta 6.41(1 \mathrm{H}, \mathrm{d}, \mathrm{J}=2.1 \mathrm{~Hz})$, $5.97(1 \mathrm{H}, \mathrm{d}, \mathrm{J}=1.5 \mathrm{~Hz}), 4.83(1 \mathrm{H}, \mathrm{d}, \mathrm{J}=5.7 \mathrm{~Hz}), 4.65(1 \mathrm{H}, \mathrm{dq}, \mathrm{J}=6.0,6.6 \mathrm{~Hz}), 1.34(3 \mathrm{H}, \mathrm{d}, \mathrm{J}=6.6 \mathrm{~Hz}) .{ }^{13} \mathrm{C} \mathrm{NMR}(75$ $\left.\mathrm{MHz}, \mathrm{CDCl}_{3}\right) \delta 168.9,138.8,126.3,78.4,69.7,14.3 . \mathrm{IR}(\mathrm{NaCl}) \delta 3439,3015,2930,1756,1672,1387,1263,1186$, 1103, 1045, 958, 910, 861, 821, $784 \mathrm{~cm}^{-1}$. HRMS m/z calcd for $\mathrm{C}_{6} \mathrm{H}_{8} \mathrm{O}_{3} \mathrm{Na}\left[\mathrm{M}+\mathrm{Na}^{+}\right]:$151.0371, found: 151.0354 .

Spectroscopic data of 19: $[\alpha]_{26}{ }^{\mathrm{D}}=-33.94\left(\mathrm{c}=1, \mathrm{CHCl}_{3}\right) .{ }^{1} \mathrm{H} \mathrm{NMR}\left(300 \mathrm{MHz}, \mathrm{CDCl}_{3}\right) \delta 7.95(2 \mathrm{H}, \mathrm{d}, \mathrm{J}=7.2 \mathrm{~Hz}), 7.72$ $(\mathrm{t}, 1 \mathrm{H}, \mathrm{J}=7.5 \mathrm{~Hz}), 7.61(\mathrm{t}, 2 \mathrm{H}, \mathrm{J}=7.8 \mathrm{~Hz}), 4.72(\mathrm{~m}, 1 \mathrm{H}), 4.63(\mathrm{~m}, 1 \mathrm{H}), 3.56(\mathrm{~m}, 2 \mathrm{H}), 3.26(\mathrm{~m}, 1 \mathrm{H}), 2.93(\mathrm{~d}, 1 \mathrm{H}, \mathrm{J}=$ $4.2 \mathrm{~Hz}), 1.49(3 \mathrm{H}, \mathrm{d}, \mathrm{J}=6.6 \mathrm{~Hz}) .{ }^{13} \mathrm{C} \mathrm{NMR}\left(75 \mathrm{MHz}, \mathrm{CDCl}_{3}\right) \delta 174.6,138.4,134.5,129.7,127.8,79.6,70.1,51.2$, 42.7, 13.6 ppm. IR $(\mathrm{NaCl}) \delta 3350,2949,2836,1764,1656,1449,1412,1117,1033 \mathrm{~cm}^{-1} . \mathrm{HRMS} \mathrm{m} / z$ calcd. for $\mathrm{C}_{12} \mathrm{H}_{14} \mathrm{O}_{5} \mathrm{SNa}\left[\mathrm{M}+\mathrm{Na}^{+}\right]: 293.0460$, found: 293.0429 .

\section{Acknowledgements}

We dedicate this work to the memory of Prof. Purificación Escribano. This work was financed by Bancaixa-UJI foundation (P1 1B2011-59 and P1 1B2011-28). The authors also are grateful to the Serveis Centrals d'Instrumentació Científica (SCIC) of the Universitat Jaume I for providing us with mass spectrometry and NMR.

Supporting Information Available: Crystallographic data (CIF), graphical NMR spectra of all compounds and ORTEP representations. This material is available free of charge via the Internet at http://pubs.acs.org.

\section{References and Footnotes}

1- Carreño, C. Chem. Rev. 1995, 95, 1717-1760.

2- Trost, B. M.; Salzmann, T. N.; Hiroi, K. J. Am. Chem. Soc. 1975, 97, 4887-4902.

3- Trost, B. M.; Leung, K. K. Tetrahedron Lett. 1975, 48, 4197-4200.

4- Trost, B. M.; Mao, M. K. T.; Balkovec, J. M.; Buhlmayer, P. J. Am. Chem. Soc. 1986, 108, 4965-4973.

5- Bänziger, M.; Kleina, S.; Rihs, G. Helv. Chim. Acta 2002, 85, 1399-1406. 
6- Kingsbury, C. A.; Cram, D. J. J. Am. Chem. Soc. 1960, 82, 1810-1819.

7- Cubagge, J. W.; Guo, Y.; McCulla, R. D.; Jenks, W. S. J. Org. Chem. 2001, 66, 8722-8736.

8- McCulla, R. D.; Jenks, W. S. J. Org. Chem. 2003, 68, 7871-7879.

9- López, I.; Izquierdo, J.; Rodríguez, S.; González, F. V. J. Org. Chem. 2007, 72, 6614-6617.

10- González, F. V.; Jain, A.; Rodríguez, S.; Sáez, J.; Vicent, C.; Peris, G. J. Org. Chem. 2010, 75, 5888-5894.

11- An aproximately 3:2 mixture of stereomeric sulfoxides was obtained in all cases (see Supporting Information).

12- The elimination reactions afforded trans isomers as the reaction product, the corresponding cis isomers were never observed (NMR spectra) nor even in trace amounts. The elimination reactions were also performed at $80{ }^{\circ} \mathrm{C}$ and the result was similar to the one carried out at $110^{\circ} \mathrm{C}$ also in this case only trans enoates were obtained.

13- Compounds 5-8 were identifed based on NMR (see Supporting Information) comparing with prior literature. For compound 5: Aldrich Library of ${ }^{13} \mathrm{C}$ and ${ }^{1} \mathrm{H}$ FT NMR spectra, 1, 973C. For compound 6: Nishizawa, M.; Hirakawa, H.; Nakagawa, Y.; Yamamoto, H.; Namba, K.; Imagawa. H. Org. Lett. 2007, 9, 5577-5580. For compound 7: Kandula, S.R.V.; Kumar, P. Tetrahedron:Asymmetry 2005, 16, 3268-3274. For compound 8: Pittelkow, M.; Christensen, J. B. Org. Lett. 2005, 7, 1295-1298.

14- Rearranged sulfoxides similar to $\mathbf{1 0}$ from the elimination reactions of compounds $\mathbf{2} \mathbf{b}-\mathbf{2} \mathbf{f}$ have been detected as traces by NMR and MS of the crude.

15- Compound $\mathbf{1 0}$ was isolated from the crossover experiment reaction mixture depicted in scheme 4, and compared with authentic sample already isolated and characterized.

16- Guo, Y.; Jenks, W. S. J. Org. Chem. 1997, 62, 857-864.

17- ESI-MS has shown to be a good technique for the detection of radicals by Tempo combination: Zhang, X.; Wang, H.; Guo, Y. Rapid Commun. Mass Spectrom. 2006, 20, 1877-1882.

18- Nitroxides as 11 are radical initiators (Macromolecules 1997, 30, 6445-6450). When the elimination reaction to trap the radical intermediate was performed at $110^{\circ} \mathrm{C}$ then compounds 14-15 were detected but 11-13 were not. Finally compounds 11-13 could be detected when the reaction was carried out at $80^{\circ} \mathrm{C}$.

19- Phenyl disulfide was isolated and charaterized (see Supporting Information) and phenyl sulfonic acid was detected by ESI-MS. For references related to the conversion of thiosulfonates into disulfides see: Pinnick, H. W.; Reynolds, M. A.; McDonald, R. T.; Brewster, W. D. J. Org. Chem. 1980, 45, 930-932 and cites herein.

20- Shelton, J. R.; Davis, K. E. J. Am. Chem. Soc. 1967, 89, 718-719.

21 - Barton, D. H. R.; Comer, F.; Greig, D. G. T.; Lucente, G.; Sammes, P.G.; Underwood, W. G. J. Chem. Soc.; Chem. Commun. 1970, 17, 1059.

22- Barton, D. H. R.; Sammes, P. G.; Taylor, M. V.; Cooper, C. M.; Hewitt, G.; Looker, B. F.; Underwood, W. G. J. Chem. Soc.; Chem. Commun. 1971, 18, 1137.

23- Carey, F. A.; Sundberg, R. J. Advanced Organic Chemistry. Part A. Ed. Kluwer Academic / Plenum Publishers 
2000, pp226.

24- Santos, L. S.; Knaack, L.; Metzger, J. O. Int. J. Mass Spectrom. 2005, 246, 84-104.

25- Eberlin, M. N. Eur. J. Mass Spectrom. 2007, 13, 19-28.

26- Santos, L. S. Eur. J. Org. Chem. 2008, 235-253.

27- Meyer, S.; Koch, R.; Metzger, J. O. Angew. Chem. Int. Ed. 2003, 42, 4700-4703.

28- Griep-Raming, J.; Metzger, J. O. Anal. Chem. 2000, 72, 5665-5668.

29- Meyer, S.; Metzger, J. O. Anal. Bioanal. Chem. 2003, 377, 1108-1114.

30- Fürmeier; S.; Metzger, J. O. J. Am. Chem. Soc. 2004, 126, 14485-14492.

31- Zhang, X.; Liao, Y.; Qian, R.; Wang, H.; Guo, Y. Org. Lett. 2005, 7, 3877-3880.

32- Schäfer, M.; Drayb, M.; Springer, A.; Zacharias, P.; Meerholz, K. Eur. J. Org. Chem. 2007, 5162-5174.

33- Cubagge, J. W.; Vos, B.W.; Jenks, W. S. J. Am. Chem. Soc. 2000, 122, 4968-4971.

34- X-ray structure of compound 19 confirmed the stereochemistry (see Supporting Information).

35- Clennan, E. L.; Kang, Y. J. Org. Chem. 1992, 57, 4477-4487. 